\title{
The Self-Administered International Prostate Symptoms Score (IPSS) Questionnaire of Kosovo Men with Benign Prostatic Hyperplasia
}

\author{
Musa Oruqi ${ }^{1}$, Elvana Podvorica2 ${ }^{2}$, Jeton Islamaj ${ }^{1}$ \\ ${ }^{1}$ Department of Urology, Clinic of Urology, University Clinical Centre of Kosovo, Pristina, Kosovo \\ ${ }^{2}$ Department of Nursing and Midwifery, Faculty of Medicine, University of Pristina, Pristina, Kosovo \\ Email: *elvana.podvorica@uni-pr.edu
}

How to cite this paper: Oruqi, M., Podvorica, E. and Islamaj, J. (2021) The SelfAdministered International Prostate Symptoms Score (IPSS) Questionnaire of Kosovo Men with Benign Prostatic Hyperplasia. Open Journal of Urology, 11, 367-379.

https://doi.org/10.4236/oju.2021.1110036

Received: August 20, 2021

Accepted: October 26, 2021

Published: October 29, 2021

Copyright $\odot 2021$ by author(s) and Scientific Research Publishing Inc. This work is licensed under the Creative Commons Attribution International License (CC BY 4.0).

http://creativecommons.org/licenses/by/4.0/

\begin{abstract}
Background: Benign prostatic hyperplasia $(\mathrm{BPH})$ has been a major health problem for aging males because of its related symptoms and complications. Although it is not a life-threatening condition, BPH has an adverse effect on a patient's quality of life, as manifested in community and clinical trials. Aim: The aim of the study was the perception of patients in their symptomatology by comparing the place of residence and quality of life in living with HBP using the IPSS questionnaire. Materials and Methods: This was a prospectively designed study conducted at University Clinical Centre of Kosovo-Urology Clinic. The study was conducted from October 2020 to January 2021. The study in criteria was as follows: all patients who presented to the urology outpatient clinic with BPH, Lower Urinary Tract Symptoms (LUTS) and aged $>40$ years. The exclusion criteria included the following cases: patients with uncontrolled diabetes (prostate-specific antigen $>4 \mathrm{ng} / \mathrm{dL}$ ); patients with a history of transurethral resection of the prostate. Results: This study was carried out on 100 consecutive patients with HBP and LUTS attending. The largest proportion of patients $51 \%$ was in the 46 - 55 age group. Most patients were between 45 - 65 years of $51 \%$. The largest number of them (52\%) was with severe symptoms and $41 \%$ of them were with moderate symptoms. Comparing the three levels of IPSS and the quality of life of patients with HBP and LUTS, when asked how they would feel if they still had problems with urination, $22 \%$ said they felt upset, analyzing the categorization of patients according to IPSS: mild symptoms were Mean/SD (1.71. \pm 1.113$)$, moderate symptoms (2.9 $\pm 1.49)$ and severe symptoms $(4.31 \pm 1.27) \mathrm{p}<0.156$. Statistical reliability of $64 \% \mathrm{p}<0.000$ was in patients where they were interested in learning about any invasive option that would allow them to discontinue medication for LUTS. Conclusion: The IPSS is a valid instrument to assess the impact of
\end{abstract}


$\mathrm{BPH}$ symptoms on health and quality of life due to urinary symptoms.

\section{Keywords}

Benign Hyperplasia, International Prostate Symptom Score, Quality of Life, Lower Urinary Tract Symptoms

\section{Introduction}

Benign prostatic hyperplasia (BPH) is a common condition as men get older. An enlarged prostate gland can cause uncomfortable urinary symptoms, such as blocking the flow of urine out of the bladder. Lower urinary tract symptoms (LUTS) due to benign prostatic hyperplasia (BPH) are common conditions in middle-age or older men [1]. The International Prostate Symptom Score (IPSS) is a useful and validated questionnaire to evaluate LUTS secondary to BPH [2]. However, BPH is considered for the vast majority of LUTS. BPH causes symptoms in approximately $90 \%$ of men over the age of 55 years old and one-third of men will develop urinary tract symptoms once in their life [3] [4] [5] [6].

The primary goal for treating men with BPH-LUTS is usually to relieve symptoms and to prevent them [7].

The most important issue is that the IPSS questionnaire should be selfadministered as this will eliminate the possible bias that may be associated with physician-assisted or health worker-assisted administration. This instrument measures the severity of voiding and storage symptoms (see Appendix) and consists of 7 items of the International Prostate Symptom Score, referred to in this article as the IPSS (see Appendix) [8]. Therefore, guidelines recommend that the IPSS questionnaire be used as a mandatory test in the evaluation and follow-up of LUTS and BPH [9].

This study was in terms of the initial evaluation of LUTS and BPH, and the assessment of changes in symptom severity before and after medication and the quality of life of patients with benign prostatic hyperplasia.

Much of the research to date has focused to evaluate the relationship between lower urinary tract symptoms (LUTS), different diagnostic indicators of benign prostatic hyperplasia (BPH) [10], and relationship between prostate inflammation and lower urinary tract symptoms (LUTS) due to benign prostate hyperplasia (BPH) has raised the urological interest in the recent years, due to new evidence that supports this potential link [11], and some of the research has focused on surgical or medical management of symptoms, but there is growing interest in identifying preventive measures for reducing the burden of LUTS by identifying risk factors associated with these symptoms, especially those that are potentially modifiable [12]. Other risk factors include comorbidities, such as diabetes, cardiovascular disease, hypertension and the side effects of the pharmacological treatments for these comorbidities [13]. Other postulated but not yet 
clearly established factors associated with LUTS include higher body mass index (BMI), lower socio-economic status, being married, family history, dietary and lifestyle factors (such as alcohol, caffeine, smoking, physical inactivity), history of sexually transmitted disease, other prostate conditions and ethnicity [11] [12] [13] [14] [15].

\section{Materials and Methods}

\subsection{Patients and Study Design}

This was a prospective, observational, study to evaluate change in Qol in patients with moderate-to-severe LUTS/BPH managed in a urological setting. The study was performed in the University Clinical Centre of Kosovo-Urology Clinic-Kosovo from October 2020 to January 2021. A total number of 100 patients who presented themselves to the urology outpatient department with LUTS due to $\mathrm{BPH}$ were enrolled in the study.

The study inclusion criteria were as follows: all patients who presented themselves to the urology outpatient clinic with BPH, LUTSs were aged $>40$ years.

The exclusion criteria included the following cases: patients with uncontrolled diabetes (prostate-specific antigen $>4 \mathrm{ng} / \mathrm{dL}$ ); patients with a history of transurethral resection of the prostate and patients who underwent surgery for urethral vesicle calculus in the past.

\subsection{Sample Size}

The selection of patients included in the study was randomized by analyzing inclusive and exclusion criteria.

\subsection{LUTS Assessment}

The collected medical histories from the enrolled patients. On their initial visit, respondents were issued IPSS (English version). The sum of IPSS questions 2, 4 and 7 related to irritative symptoms: and the sum of IPSS questions 1, 3, 5 and 6 related to obstructive symptoms.

\section{Follow-Up and Outcomes}

Patients with symptoms score of 20 - 35 had severe symptoms of IPSS where $52 \%$ of them were treated with Alpha Receptor Blockers, 5 alpha-reductase inhibitors and prostatectomy (TUR-P, PTV), while patients with moderate symptoms $(41 \%)$ were treated with 5 alpha-reductase inhibitors and herbal extracts, and patients with mild symptoms (7\%) were treated with careful observation and waiting and herbal extracts.

The questionnaire consists of seven questions on incomplete bladder emptying, frequency of micturition, intermittency, urgency, weak stream, straining and nocturia. There is an $8^{\text {th }}$ question on the quality-of-life assessment in relation to the urinary symptoms. 


\section{Statistical Analysis}

Values are expressed as Mean \pm SD for continuous variables and percentage for dichotomous data. Continuous data was compared with two-tailed Student $t$-test and discrete data with Chi-square test. Quantitative data was analyzed through the SPSS statistical program.

\section{Results}

This study was carried out on 100 consecutive patients suffering with HBP and LUTS. The average age of the participants was $69 \pm 0.726$. From 100 patients surveyed $7 \%$ of them had mild symptoms, $41 \%$ had moderate symptoms and the largest number of them $52 \%$ had severe symptoms. Most of the participants (76\%) were married, (90\%) were Albanian. Regarding education level most of them (36\%) were only educated at primary school level or below. Higher proportions of them $(53 \%)$ were pensioners. $51 \%$ of them were living in a village. The majority of the participants were Muslim (92\%) and (55\%) of them were smokers. When asked if they use the Anti-hypertensive drugs, the majority of the patients declared yes (68\%), whereas (32\%) declared no. When questioned about a family history of prostate disease, $67 \%$ of them declared that they did not have a history of this in their family (Table 1).

Regarding the symptomatology between patients living in the city and in a village: out of 100 patients, most of them (29\%) stated that they had the feeling of not emptying the bladder less than one in five times. Comparing the place of settlement, we did not find a statistically significant relationship between the settlement in the village and in the city: Village Mean-SD $(2.63 \pm 1.37)$ and Mean Rank 55.52, while Mean-SD city (2.14 \pm 1.36$)$ and Mean Rank $45.2 \mathrm{p}<0.679$. In terms of frequency when comparing patients living rurally and in urban areas, we did not gain a statistically significant relationship: Village (2.61 \pm 1.41$)$, Mean Rank: 54.85, City $(2.14 \pm 1.30)$, Mean Rank $45.97 \mathrm{p}<0.203$. Regarding the interval of urination, $30 \%$ of the patients had to stop and start the act of urination again. Comparing the place of residence, I did not find a statistical reliability $\mathrm{p}<$ 0.338 . $24 \%$ of patients had emergency urination $\mathrm{p}<0.36$. Most patients, $32 \%$ of them, had low blood pressure during urination $\mathrm{p}<0.25$. In answer to the question: how often they have had to push or strain to begin urination, most of them (36\%) had to do this almost always. We compared this with village residence: (3.25 \pm 1.27$)$, Mean Rank 54.79 and patients living in the city (2.9 \pm 1.27$)$ Mean Rank $46.03 \mathrm{p}<0.256 .28 \%$ of them urinate 2 times per night $\mathrm{p}<0.256$ (Table 2).

According to the terms of IPSS categorization most patients (52\%) were experiencing severe symptoms, $41 \%$ had moderate symptoms and only $7 \%$ had mild symptoms.

Comparing the three levels of IPSS and the quality of life of patients with HBP and LUTS, when asked how they would feel if they still had problems with urination, $22 \%$ of them said that they would feel upset. Analyzing the categorization of patients according to IPSS: mild symptoms were: Mean/SD (1.71 \pm 1.113$)$, 
Table 1. Main socio-demographic and health conditions results $(\mathrm{n}=100)$.

\begin{tabular}{|c|c|c|c|}
\hline Characteristics & $\mathbf{N}$ & & $\%$ \\
\hline \multicolumn{4}{|c|}{ Age } \\
\hline 46 - 55 years old & 22 & & 22 \\
\hline 56 - 65 years old & 47 & & 47 \\
\hline$>66$ years old & 31 & & 31 \\
\hline Minimum & \multicolumn{3}{|c|}{46} \\
\hline Maximum & \multicolumn{3}{|c|}{85} \\
\hline Median & \multicolumn{3}{|c|}{65} \\
\hline Mean (SD) & \multicolumn{3}{|c|}{$69( \pm 0.726)$} \\
\hline \multicolumn{4}{|c|}{ Marital status } \\
\hline Married & 76 & & 76 \\
\hline Divorced & 8 & & 8 \\
\hline Single & 16 & & 16 \\
\hline \multicolumn{4}{|c|}{ Ethnicity } \\
\hline Albania & 90 & & 90 \\
\hline Turkish & 6 & & 6 \\
\hline Bosnian & 1 & & 1 \\
\hline Egyptian & 3 & & 3 \\
\hline \multicolumn{4}{|c|}{ Education level } \\
\hline Below primary school & 36 & & 36 \\
\hline Junior high school & 25 & & 25 \\
\hline High school or some college & 36 & & 36 \\
\hline University or above & 3 & & 3 \\
\hline \multicolumn{4}{|c|}{ Professional status } \\
\hline Employed & 36 & & 36 \\
\hline Unemployed & 11 & & 11 \\
\hline Pensioner & 53 & & 53 \\
\hline \multicolumn{4}{|c|}{ Living place } \\
\hline City & 49 & & 49 \\
\hline Village & 51 & & 51 \\
\hline \multicolumn{4}{|c|}{ Smoking } \\
\hline No & 45 & & 45 \\
\hline Yes & 55 & & 55 \\
\hline \multicolumn{4}{|c|}{ If you smoke } \\
\hline$>10$ cigarettes a day & 32 & & 32 \\
\hline$>20$ cigarettes a day & 23 & & 23 \\
\hline \multicolumn{4}{|c|}{ Anti-hypertensive drugs use } \\
\hline Yes & 68 & & 68 \\
\hline No & 32 & & 32 \\
\hline
\end{tabular}




\section{Continued}

\section{Anti-diabetic drugs use}

Yes

No

Yes

No

Very good

Good

Bad

Very bad
22

78

Family history of prostate disease

67
22

78

67

According to you, In general your health is?

\begin{tabular}{ll}
7 & 7 \\
53 & 53 \\
38 & 38 \\
& \\
\hline
\end{tabular}

2

Table 2. Symptomatology between patient's perception to living in the center and village.

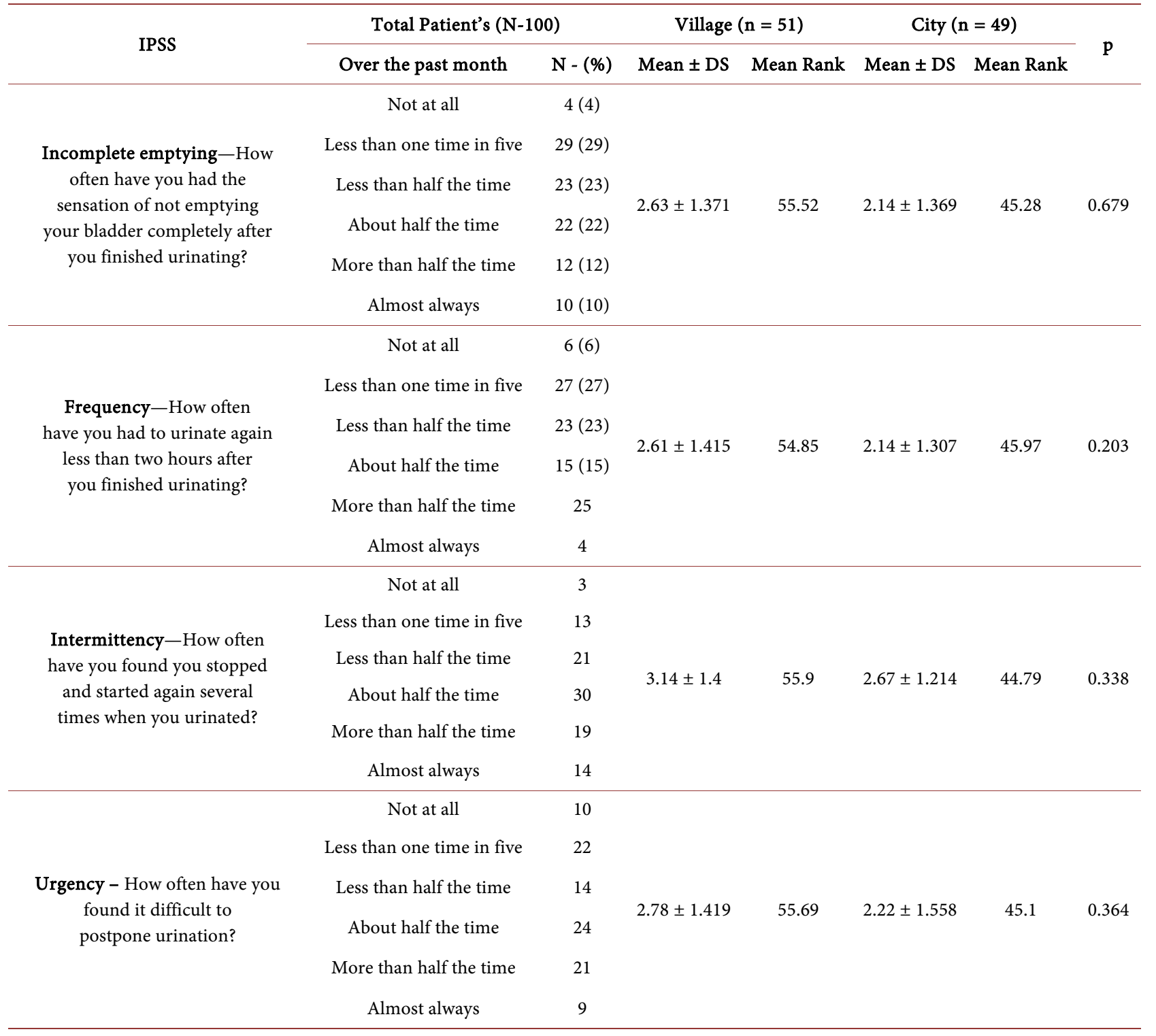




\begin{tabular}{|c|c|c|c|c|c|c|c|}
\hline \multirow{6}{*}{$\begin{array}{l}\text { Weak stream-How often } \\
\text { have you had a weak } \\
\text { urinary stream? }\end{array}$} & Not at all & 1 & \multirow{6}{*}{$3.65 \pm 1.547$} & \multirow{6}{*}{55.32} & \multirow{6}{*}{$3.35 \pm 1.284$} & \multirow{6}{*}{45.48} & \multirow{6}{*}{0.038} \\
\hline & Less than one time in five & 13 & & & & & \\
\hline & Less than half the time & 13 & & & & & \\
\hline & About half the time & 11 & & & & & \\
\hline & More than half the time & 32 & & & & & \\
\hline & Almost always & 30 & & & & & \\
\hline \multirow{6}{*}{$\begin{array}{l}\text { Straining-How often } \\
\text { have you had to push or } \\
\text { strain to begin urination? }\end{array}$} & Not at all & 3 & \multirow{6}{*}{$3.61 \pm 1.626$} & \multirow{6}{*}{54.16} & \multirow{6}{*}{$3.37 \pm 1.395$} & \multirow{6}{*}{46.69} & \multirow{6}{*}{0.49} \\
\hline & Less than one time in five & 10 & & & & & \\
\hline & Less than half the time & 17 & & & & & \\
\hline & About half the time & 11 & & & & & \\
\hline & More than half the time & 23 & & & & & \\
\hline & Almost always & 36 & & & & & \\
\hline \multirow{6}{*}{$\begin{array}{l}\text { Sleeping-How many times } \\
\text { did you most typically get } \\
\text { up to urinate from the time } \\
\text { you went to bed at night } \\
\text { until the time you } \\
\text { got up in the morning? }\end{array}$} & None & & \multirow{6}{*}{$3.25 \pm 1.278$} & \multirow{6}{*}{54.79} & \multirow{6}{*}{$2.9 \pm 1.279$} & \multirow{6}{*}{46.03} & \multirow{6}{*}{0.256} \\
\hline & One Time & 11 & & & & & \\
\hline & Two Times & 28 & & & & & \\
\hline & Three Times & 20 & & & & & \\
\hline & Four Times & 24 & & & & & \\
\hline & Five or More Times & 17 & & & & & \\
\hline
\end{tabular}

Moderate symptoms $(2.9 \pm 1.49)$ and severe symptoms $(4.31 \pm 1.27) \mathrm{p}<0.156$. Statistical reliability of $64 \% \mathrm{p}<0.000$ was in patients where they were interested in learning about any invasive option that would allow them to discontinue medication for LUTS (Tables 3-5).

\section{Discussion}

The purpose of this study is to evaluate psychometric properties including validity and quality of life patients with BPH using the IPSS instrument in male patients with $\mathrm{BPH}$ under tertiary care.

This study has evaluated changes in symptoms and QoL in a large cohort of patients with LUTS/BPH managed in conditions of real-life practice. We observed significant improvements in interested in learning about a minimally invasive option that could allow you to discontinue your BPH medications.

A relevant contribution of this study is that is assesses the effect on QoL of several medical treatments for LUTS/BPH used in real life practice by means of an internationally recognized, validated questionnaire that is easy to use in regular clinical practice, whereas earlier studies tended to focus almost exclusively on symptoms [16] [17] [18] or on outcomes associated with a single drug [19] [20]. In the present study, treatment regimens were chosen by participating urologists based on their current practice, and the distribution of patients across different pharmacological options is in line with data published in a previous report [18] [21]. 
Table 3. Quality of life and IPSS assessment.

\begin{tabular}{|c|c|c|c|}
\hline \multicolumn{2}{|c|}{ Symptomatology and categorization } & \multirow{2}{*}{$\begin{array}{l}\mathrm{N} \\
7\end{array}$} & \multirow{2}{*}{$\begin{array}{c}\text { Mean Rank } \\
18.07\end{array}$} \\
\hline \multirow{4}{*}{$\begin{array}{l}\text { If you were to spend the rest of your life with } \\
\text { your urinary condition just the way it is now, } \\
\text { how would you feel about that? }\end{array}$} & $1-7$ mild symptoms & & \\
\hline & $8-19$ moderate symptoms & 41 & 38.98 \\
\hline & 20 - 35 severe symptoms & 52 & 63.95 \\
\hline & Total & 100 & \\
\hline \multirow{4}{*}{$\begin{array}{l}\text { Have you tried medications } \\
\text { to help your symptoms? }\end{array}$} & $1-7$ mild symptoms & 7 & 45.5 \\
\hline & $8-19$ moderate symptoms & 41 & 52.82 \\
\hline & $20-35$ severe symptoms & 52 & 49.35 \\
\hline & Total & 100 & \\
\hline \multirow{4}{*}{$\begin{array}{l}\text { Did these medications help } \\
\text { your symptoms? (circle) }\end{array}$} & $1-7$ mild symptoms & 7 & 82.93 \\
\hline & 8 - 19 moderate symptoms & 41 & 64.88 \\
\hline & 20 - 35 severe symptoms & 52 & 34.8 \\
\hline & Total & 100 & \\
\hline \multirow{4}{*}{$\begin{array}{c}\text { Would you be interested in learning about a minimally } \\
\text { invasive option that could allow you to discontinue } \\
\text { your BPH medications? }\end{array}$} & $1-7$ mild symptoms & 7 & 75.36 \\
\hline & 8 - 19 moderate symptoms & 41 & 56.89 \\
\hline & 20 - 35 severe symptoms & 52 & 42.12 \\
\hline & Total & 100 & \\
\hline
\end{tabular}

Table 4. Quality of life and IPSS assessment test statistics ${ }^{\mathrm{a}, \mathrm{b}}$.

\begin{tabular}{ccccc}
\hline & $\begin{array}{c}\text { If you were to spend the rest } \\
\text { of your life with your urinary } \\
\text { condition just the way it is now, } \\
\text { how would you feel about that? }\end{array}$ & $\begin{array}{c}\text { Have you tried } \\
\text { medications to } \\
\text { help your symptoms? }\end{array}$ & $\begin{array}{c}\text { Did these medications } \\
\text { help your symptoms? } \\
\text { (circle) }\end{array}$ & $\begin{array}{c}\text { Would you be interested in learning } \\
\text { about a minimally invasive option } \\
\text { that could allow you to discontinue } \\
\text { your BPH medications? }\end{array}$ \\
\hline $\begin{array}{l}\text { Chi-Square } \\
\text { df }\end{array}$ & 27.318 & 2.043 & 34.504 & 16.595 \\
Asymp. Sig. & 2 & 2 & 2 & 0 \\
\hline
\end{tabular}

a. Kruskal Wallis Test; b. Grouping variable.

Table 5. Quality of life and IPSS assessment.

\begin{tabular}{|c|c|c|c|c|c|c|c|c|c|}
\hline \multirow{3}{*}{ Quality of Life (QoL) } & \multirow{3}{*}{ Variable } & \multirow{3}{*}{$\mathrm{N}-100$} & \multirow{2}{*}{\multicolumn{2}{|c|}{$\begin{array}{c}\begin{array}{c}1-7 \\
\text { mild symptoms }\end{array} \\
\mathrm{N}-7\end{array}$}} & \multirow{2}{*}{\multicolumn{2}{|c|}{$\begin{array}{c}8-19 \\
\text { moderate symptoms } \\
\mathrm{N}-41\end{array}$}} & \multirow{2}{*}{\multicolumn{2}{|c|}{$\begin{array}{c}20-35 \\
\text { severe symptoms } \\
\mathrm{N}-52\end{array}$}} & \multirow{3}{*}{$\mathrm{P}$} \\
\hline & & & & & & & & & \\
\hline & & & Mean & $\mathrm{SD}$ & Mean & SD & Mean & SD & \\
\hline \multirow{7}{*}{$\begin{array}{l}\text { If you were to spend the rest } \\
\text { of your life with your urinary } \\
\text { condition just the way it is } \\
\text { now, how would you feel } \\
\text { about that? }\end{array}$} & Delighted & 0 & \multirow{7}{*}{1.71} & \multirow{7}{*}{1.113} & \multirow{7}{*}{2.9} & \multirow{7}{*}{1.497} & \multirow{7}{*}{4.31} & \multirow{7}{*}{1.276} & \multirow{7}{*}{0.156} \\
\hline & Pleased & 11 & & & & & & & \\
\hline & Mostly Satisfied & 22 & & & & & & & \\
\hline & Mixed & 13 & & & & & & & \\
\hline & Mostly Dissatisfied & 22 & & & & & & & \\
\hline & Unhappy & 19 & & & & & & & \\
\hline & Terrible & 13 & & & & & & & \\
\hline
\end{tabular}




\begin{tabular}{|c|c|c|c|c|c|c|c|c|c|}
\hline $\begin{array}{l}\text { Have you tried medications } \\
\text { to help your symptoms? }\end{array}$ & $\begin{array}{l}\text { Yes } \\
\text { No }\end{array}$ & $\begin{array}{l}90 \\
10\end{array}$ & 0.00 & 0.000 & 0.15 & 0.358 & 0.08 & 0.269 & 0.013 \\
\hline \multirow{8}{*}{$\begin{array}{l}\text { Did these medications help } \\
\text { your symptoms? (circle) }\end{array}$} & 1 & 8 & \multirow{8}{*}{8.43} & \multirow{8}{*}{3.309} & \multirow{8}{*}{6.51} & \multirow{8}{*}{2.215} & \multirow{8}{*}{3.69} & \multirow{8}{*}{2.044} & \multirow{8}{*}{0.674} \\
\hline & 2 & 13 & & & & & & & \\
\hline & 3 & 15 & & & & & & & \\
\hline & 4 & 7 & & & & & & & \\
\hline & 5 & 12 & & & & & & & \\
\hline & 6 & 11 & & & & & & & \\
\hline & 7 & 6 & & & & & & & \\
\hline & 8 & 13 & & & & & & & \\
\hline \multirow{2}{*}{$\begin{array}{l}\text { Would you be interested in learning } \\
\text { about a minimally invasive option } \\
\text { that could allow you to } \\
\text { discontinue your BPH medications? }\end{array}$} & Yes & 64 & \multirow{2}{*}{0.86} & \multirow{2}{*}{0.378} & \multirow{2}{*}{0.49} & \multirow{2}{*}{0.506} & \multirow{2}{*}{0.19} & \multirow{2}{*}{0.398} & \multirow{2}{*}{0.000} \\
\hline & No & 36 & & & & & & & \\
\hline
\end{tabular}

In item-total correlation testing, the symptom-related item of nocturia and incomplete emptying feeling had a poor correlation. The results suggest that this item is being measured in a related yet slightly different domain than the other items of the IPSS. This result isn't similar to that of a previous validation study carried in Brazil [19].

Some studies have already demonstrated an association between nocturia and poorer HRQoL in men with BPH. Van Dijk et al. [19] reported that among the symptoms assessed by the IPSS questionnaire, nocturia, urgency and weak stream associated with poorer QoL. Storage symptoms such as urgency, increased frequency, and nocturia reportedly have a greater impact on QoL than voiding symptoms [20]. In our study, nocturia (20\% were three times, $24 \%$ four times and $17 \%$ five or more times), frequency (23\% were Less than half the time, $15 \%$ about half the time and $25 \%$ more than half the time) and incomplete emptying (23\% were less than half the time, $22 \%$ about half the time and more than half the time were $12 \%$ ), had a negative impact on the QoL in men with BPH.

In this study the patient's classification according to IPSS showed that most of them $52 \%$ experienced severe symptoms, $41 \%$ had moderate symptoms and only $7 \%$ had mild symptoms. Comparing the three levels of IPSS and the quality of life of patients with HBP and LUTS, when asked how you would feel if you still had problems with urination, $22 \%$ said they would feel upset, analyzing the categorization of patients according to IPSS: Mild symptoms were: Mean/SD (1.71. $\pm 1.113)$, moderate symptoms $(2.9 \pm 1.49)$ and severe symptoms $(4.31 \pm 1.27) \mathrm{p}$ $<0.156$. The statistical reliability of $64 \% \mathrm{p}<0.000$ was in patients where they were interested in learning about any invasive option that would allow them to discontinue medication for LUTS.

A study was done in Nigeria [22] to determine the value of IPSS in the management of patients with BPH. Using pre-treatment IPSS, patients were divided 
into 3 groups: mild, moderate, and severe symptoms groups. Patients with mild symptoms were treated with careful observation and waiting as a mode of management. The moderate symptoms group received doxazosin (a-blocker) \& antimuscarinics, while the severe symptoms group was treated by prostatectomy. The positive predictive value (PPV) of post treatment symptoms improvement was found out to be $87 \%$ for the severe group and $52 \%$ for the moderate group as measured by IPSS/QOL [23]. The study concluded that IPSS is a valuable tool in management of patients with $\mathrm{BPH}$.

\section{Limitations}

Subjects in the present study were only recruited by a convenience sampling in Urology Clinic. The psychometric performance of these measures should be further tested with Albania speakers of different nationalities as all subjects in this study were knew Albanian speakers.

\section{Conclusion}

The results demonstrate that IPSS is reliable, shows responsiveness, and has constructive validity. The IPSS is a valid instrument to assess the impact of BPH symptoms on health and quality of life due to urinary symptoms.

This assessment measures the quality of life of living with benign prostatic hyperplasia according to the IPSS scale classification.

\section{Conflicts of Interest}

None.

\section{References}

[1] Cornu, J.N., Cussenot, O., Haab, F. and Lukacs, B. (2010) A Widespread Population Study of Actual Medical Management of Lower Urinary Tract Symptoms Related to Benign Prostatic Hyperplasia across Europe and beyond Official Clinical Guidelines. European Urology, 58, 450-456. https://doi.org/10.1016/j.eururo.2010.05.045

[2] Barry, M.J., Fowler Jr., F.J., O’Leary, M.P., Bruskewitz, R.C., Holtgrewe, H.L., Mebust, W.K., et al. (1992) The American Urological Association Symptom Index for Benign Prostatic Hyperplasia. Journal of Urology, 148, 1549-1557. https://doi.org/10.1016/S0022-5347(17)36966-5

[3] Grossfeld, G.D. and Coakley, FV. (2000) Benign Prostatic Hyperplasia: Clinical Overview and Value of Diagnostic Imaging. Radiologic Clinics of North America, 38, 31-47. https://doi.org/10.1016/S0033-8389(05)70148-2

[4] Girman, C.J. (1998) Population-Based Studies of the Epidemiology of Benign Prostatic Hyperplasia. British Journal of Urology, 82, 34-43. https://doi.org/10.1046/j.1464-410X.1998.0820s1034.x

[5] Lepor, H. (2004) Pathophysiology, Epidemiology, and Natural History of Benign Prostatic Hyperplasia. Reviews in Urology, 6, S3-S10. https://doi.org/10.1111/j.1742-1241.2007.01635.x

[6] Emberton, M., Marberger, M. and De la Rosette, J. (2008) Understanding Patient and Physician Perceptions of Benign Prostatic Hyperplasia in Europe: The Prostate Research on Behaviour and Education (PROBE) Survey. International Journal of 
Clinical Practice, 62, 18-26. https://doi.org/10.1111/j.1742-1241.2007.01635.x

[7] Barry, M.J. (2001) Evaluation of Symptoms and Quality of Life in Men with Benign Prostatic Hyperplasia. Urology, 58, 25-32. https://doi.org/10.1016/S0090-4295(01)01300-0

[8] https://ncusandiego.com/assets/bph-questionnaire.pdf

[9] McVary, K.T., Roehrborn, C.G., Avins, A.L., Barry, M.J., Bruskewitz, R.C., Donnell, R.F., et al. (2011) Update on AUA Guideline on the Management of Benign Prostatic Hyperplasia. Journal of Urology, 185, 1793-1803.

https://doi.org/10.1016/j.juro.2011.01.074

[10] Ozayar, A., Zumrutbas, A.E. and Yaman, O. (2008) The Relationship between Lower Urinary Tract Symptoms (LUTS), Diagnostic Indicators of Benign Prostatic Hyperplasia (BPH), and Erectile Dysfunction in Patients with Moderate to Severely Symptomatic BPH. International Urology and Nephrology, 40, 933-939. https://doi.org/10.1007/s11255-008-9386-Z

[11] Michael, S. and Stavros, G. (2018) Chapter 3. The Relationship between Inflammation and LUTS/BPH. In: Morgia, G. and Ivan Russo, G., Eds., Lower Urinary Tract Symptoms and Benign Prostatic Hyperplasia, Academic Press, Cambridge, 31-50. https://doi.org/10.1016/B978-0-12-811397-4.00003-2

[12] Wennberg, A.L., Altman, D., Lundholm, C., Klint, A., Iliadou, A., et al. (2011) Genetic Influences Are Important for Most but not All Lower Urinary Tract Symptoms: A Population-Based Survey in a Cohort of Adult Swedish Twins. European Urology, 59, 1032-1038. https://doi.org/10.1016/j.eururo.2011.03.007

[13] Rohrmann, S., Smit, E., Giovannucci, E. and Platz, E.A. (2004) Associations of Obesity with Lower Urinary Tract Symptoms and Noncancer Prostate Surgery in the Third National Health and Nutrition Examination Survey. American Journal of Epidemiology, 159, 390-397. https://doi.org/10.1093/aje/kwh060

[14] Suzuki, S., Platz, E.A., Kawachi, I., Willett, W.C. and Giovannucci, E. (2002) Intakes of Energy and Macronutrients and the Risk of Benign Prostatic Hyperplasia. American Journal of Clinical Nutrition, 75, 689-697. https://doi.org/10.1093/ajcn/75.4.689

[15] Latz, I., Weber, M., Korda, R., Smith, D., Clements, M., et al. (2013) Lower Urinary Tract Symptoms in Relation to Region of Birth in 95,393 Men Living in Australia: The 45 and Up Study. World Journal of Urology, 31, 673-682. https://doi.org/10.1007/s00345-012-0937-7

[16] Batista, J.E., Palacio, A., Torrubia, R., Hernández, C., Vicente, J., Resel, L., et al. (2002) Tamsulosin: Effect on Quality of Life in 2740 Patients with Lower Urinary Tract Symptoms Managed in Real-Life Practice in Spain. Archivos Españoles de Urología, 55, 97-105.

[17] Hutchison, A., Farmer, R., Verhamme, K., Berges, R. and Navarrete, R.V. (2007) The Efficacy of Drugs for the Treatment of LUTS/BPH, a Study in 6 European Countries. European Urology, 51, 207-216.

https://doi.org/10.1016/j.eururo.2006.06.012

[18] Desgrandchamps, F., Droupy, S., Irani, J., Saussine, C. and Comenducci, A. (2006) Effect of Dutasteride on the Symptoms of Benign Prostatic Hyperplasia, and Patient Quality of Life and Discomfort, in Clinical Practice. BJU International, 98, 83-88. https://doi.org/10.1111/j.1464-410X.2006.06241.X

[19] de Paula Miranda, E., Mendes Gomes, C., César Miranda Torricelli, F., de Bessa, J., Everton de Castro, J., Gustavo Scafuri, A., et al. (2014) Nocturia Is the Lower Urinary Tract Symptom with Greatest Impact on Quality of Life of Men from a Commu- 
nity Setting. International Neurourology, 18, 86-90.

https://doi.org/10.5213/inj.2014.18.2.86

[20] Masumori, N., Tanaka, Y., Takahashi, A., Itoh, N., Ogura, H., Furuya, S., et al. (2003) Lower Urinary Tract Symptoms of Men Seeking Medical Care-Comparison of Symptoms Found in the Clinical Setting and in a Community Study. Urology, 62, 266-272. https://doi.org/10.1016/S0090-4295(03)00252-8

[21] Lukacs, B., Grange, J.C. and Comet, D. (2000) One-Year Follow-Up of 2829 Patients with Moderate to Severe Lower Urinary Tract Symptoms Treated with Alfuzosin in General Practice according to IPSS and a Health-Related Quality-of-Life Questionnaire. BPM Group in General Practice. Urology, 55, 540-546.

https://doi.org/10.1016/S0090-4295(99)00539-7

[22] Amu, O., Udeh, E., Ugochukwu, A., Dakum, N. and Ramyil, V. (2013) The Value of International Prostate Symptom Scoring System in the Management of BPH in Jos, Nigeria. Nigerian Journal of Clinical Practice, 16, 273-278.

https://doi.org/10.4103/1119-3077.113446

[23] Ogwuche, E.I., Dakum, N.K., Amu, C.O., Dung, E.D., Udeh, E. and Ramyil, V.M. (2013) Problems with Administration of International Prostate Symptom Score in a Developing Community. Annals of African Medicine, 12, 171-173.

https://doi.org/10.4103/1596-3519.117628 


\section{Appendix}

International Prostate Symptom Score (IPSS)

Patient Name:

Today's Date:

Determine Your BPH Symptoms

Circle your answers and add up your scores at the bottom.

\begin{tabular}{|c|c|c|c|c|c|c|}
\hline Over the past month & $\begin{array}{l}\text { Not } \\
\text { at all }\end{array}$ & $\begin{array}{l}\text { Less } \\
\text { than one } \\
\text { time in } \\
\text { five }\end{array}$ & $\begin{array}{l}\text { Less } \\
\text { than half } \\
\text { the time }\end{array}$ & $\begin{array}{l}\text { About } \\
\text { half the } \\
\text { time }\end{array}$ & $\begin{array}{l}\text { More } \\
\text { than half } \\
\text { the time }\end{array}$ & $\begin{array}{l}\text { Almost } \\
\text { always }\end{array}$ \\
\hline $\begin{array}{l}\text { Incomplete emptying - How often have you had the } \\
\text { sensation of not emptying your bladder completely after } \\
\text { you finished urinating? }\end{array}$ & 0 & 1 & 2 & 3 & 4 & 5 \\
\hline $\begin{array}{l}\text { Frequency - How often have you had to urinate again } \\
\text { less than two hours after you finished urinating? }\end{array}$ & 0 & 1 & 2 & 3 & 4 & 5 \\
\hline $\begin{array}{l}\text { Intermittency - How often have you found you stopped } \\
\text { and started again several times when you urinated? }\end{array}$ & 0 & 1 & 2 & 3 & 4 & 5 \\
\hline $\begin{array}{l}\text { Urgency - How often have you found it difficult to } \\
\text { postpone urination? }\end{array}$ & 0 & 1 & 2 & 3 & 4 & 5 \\
\hline $\begin{array}{l}\text { Weak stream - How often have you had a weak } \\
\text { urinary stream? }\end{array}$ & 0 & 1 & 2 & 3 & 4 & 5 \\
\hline $\begin{array}{l}\text { Straining - How often have you had to push or strain to } \\
\text { begin urination? }\end{array}$ & 0 & 1 & 2 & 3 & 4 & 5 \\
\hline $\begin{array}{l}\text { Sleeping - How many times did you most typically get } \\
\text { up to urinate from the time you went to bed at night } \\
\text { until the time you got up in the morning? }\end{array}$ & $\begin{array}{c}\text { None } \\
0\end{array}$ & $\begin{array}{l}\text { One } \\
\text { Time } \\
\text { I }\end{array}$ & $\begin{array}{l}\text { Two } \\
\text { Times } \\
2\end{array}$ & $\begin{array}{l}\text { Three } \\
\text { Times } \\
3\end{array}$ & $\begin{array}{l}\text { Four } \\
\text { Times } \\
4\end{array}$ & $\begin{array}{l}\text { Five or More } \\
\text { Times } \\
5\end{array}$ \\
\hline Add Symptom Scores: & & & 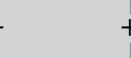 & & - & + \\
\hline
\end{tabular}

Total International Prostate Symptom Score $=$

Quality of Life (QoL)

I - 7 mild symptoms | 8-19 moderate symptoms | 20-35 severe symptoms Regardless of the score, if your symptoms are bothersome you should notify your doctor.

\begin{tabular}{|c|c|c|c|c|c|c|c|}
\hline & Delighted & Pleased & $\begin{array}{l}\text { Mostly } \\
\text { Satisfied }\end{array}$ & Mixed & $\begin{array}{c}\text { Mostly } \\
\text { Dissatisfied }\end{array}$ & Unhappy & Terrible \\
\hline $\begin{array}{l}\text { If you were to spend the rest } \\
\text { of your life with your urinary } \\
\text { condition just the way it is } \\
\text { now, how would you feel } \\
\text { about that? }\end{array}$ & 0 & 1 & 2 & 3 & 4 & 5 & 6 \\
\hline \multicolumn{6}{|c|}{ Have you tried medications to help your symptoms? } & Yes & No \\
\hline
\end{tabular}

Did these medications help your symptoms? (circle)

\begin{tabular}{|l|l|l|l|l|l|l|l|l|l|}
\hline 1 & 2 & 3 & 4 & 5 & 6 & 7 & 8 & 9 & 10 \\
\hline
\end{tabular}

No Relief

Complete Relief

Would you be interested in learning about a minimally invasive option that could allow you to discontinue your BPH medications?

Yes No

